\title{
IDENTIFIKASI BAHAYA, PENILAIAN RISIKO DAN UPAYA PENGENDALIAN PADA PROSES PENGELOLA LIMBAH MEDIS RUMAH SAKIT MUHAMMADIYAH LAMONGAN
}

\author{
HAZARDS IDENTIFICATION, RISK ASSESSMENT AND CONTROL \\ EFFORTS ON THE MANAGEMENT OF MEDICAL WASTE IN LAMONGAN \\ MUHAMMADIYAH HOSPITAL
}

\author{
Alif Kurnia Masita, Indriati Paskarini \\ Departemen Keselamatan dan Kesehatan Kerja \\ Fakultas Kesehatan Masyarakat Universitas Airlangga Surabaya \\ E-mail: alif.masita11@gmail.com
}

\begin{abstract}
The hospital have a high risk of occupational diseases and accidents at work. Medical waste can transmission of the disease on the medical waste management officers. Therefore, it was necessary to minimize accidents and disease transmission. The purpose of this research to identify hazards, risk analysis, risk evaluation, and the control efforts on the management of medical waste in Lamongan Muhammadiyah Hospital. This was a cross sectional study with descriptive analysis. Interviews and observations conducted at 6 medical waste management officers. The research variables are potential hazards, level of risk and control efforts on the hospital's medical waste management. Potential hazards found in this research that the noise hazard, high temperature, moisture, puncture wounds, contact with medical waste, contamination, disease transmission, injury, and muscle fatigue. Based on the risk analysis found that exposure levels were categorized with high frequency. Found the risk of risk evaluation in this study is that containing a very high risk, risk priority 1, big risk, risk priority 3, and acceptable risk. Control measures undertaken by the hospital to the risk that controls with engineering, administrative and personal protective equipment (PPE). The efforts should be by the medical waste management officers to reduce the risk with used the personal protective equipment (PPE) that have been provided by the hospital at work.
\end{abstract}

Keywords: hazard identification, risk assessment, medical waste

\begin{abstract}
ABSTRAK
Rumah sakit memiliki risiko tinggi terhadap penyakit akibat kerja dan kecelakaan kerja. Limbah medis dapat menjadi sarana penularan penyakit pada petugas pengelola limbah. Oleh karena itu, diperlukan upaya untuk meminimalisasi kecelakaan dan penularan penyakit. Tujuan dalam penelitian ini adalah melakukan identifikasi bahaya, analisis risiko, evaluasi risiko, serta upaya pengendalian pada proses pengelolaan limbah medis di Rumah Sakit Muhammadiyah Lamongan. Penelitian ini menggunakan rancangan cross sectional dengan analisa deskriptif. Wawancara dan observasi dilaksanakan pada 6 petugas pengelola limbah medis. Variabel penelitian adalah potensi bahaya, tingkat risiko dan upaya pengendalian pada proses pengelolaan limbah medis rumah sakit. Potensi bahaya yang ditemukan pada penelitian ini yaitu bahaya kebisingan, suhu tinggi, kelembapan, luka tusuk, kontak dengan limbah medis, kontaminasi, penularan penyakit, cidera, dan kelelahan otot. Berdasarkan analisis risiko ditemukan bahwa tingkat paparan dikategorikan dengan frekuensi tinggi. Risiko yang ditemukan dari evaluasi risiko pada penelitian ini adalah terdapat risiko sangat tinggi, risiko prioritas 1 , risiko besar, risiko prioritas 3 , dan risiko diterima. Upaya pengendalian yang dilakukan oleh rumah sakit terhadap risiko yaitu pengendalian secara teknik, administratif dan alat pelindung diri (APD). Upaya yang seharusnya dilakukan oleh petugas pengelola limbah untuk mengurangi risiko yang yaitu dengan menggunakan alat pelindung diri yang telah disediakan oleh rumah sakit pada saat bekerja.
\end{abstract}

Kata kunci: identifikasi bahaya, penilaian risiko, limbah medis

\section{PENDAHULUAN}

Undang-Undang No. 44 Tahun 2009 tentang Rumah sakit menjelaskan bahwa rumah sakit adalah institusi pelayanan kesehatan perorangan secara paripurna yang menyedihkan pelayanan rawat inap, 
rawat jalan, dan gawat darurat. Pada pasal 11 tertulis bahwa prasarana yang ada di rumah sakit harus memenuhi standar pelayanan, keamanan, serta keselamatan dan kesehatan kerja bagi penyelenggara rumah sakit. Hal tersebut dimaksudkan agar hak perlindungan terhadap pekerja/buruh di rumah sakit dapat diwujudkan. Penyelenggaraan kesehatan dan keselamatan kerja di rumah sakit (K3RS) perlu mendapat perhatian serius karena tidak hanya menyangkut tenaga medis dan pasien, akan tetapi juga menyangkut pengunjung serta tenaga non medis seperti pengelola rumah sakit dan pelaksana.

Hasil kajian tentang pengelolaan limbah di 100 rumah sakit di Jawa dan Bali yang terdapat dalam profil kesehatan Indonesia menunjukkan ratarata produksi sampah rumah sakit sebesar $3,2 \mathrm{~kg}$ limbah padat per tempat tidur per hari sedangkan produksi limbah cair sebesar 416,8 liter per tempat tidur setiap hari (Depkes, 2006). Limbah yang dihasilkan meliputi limbah infeksius dan limbah domestik. Rumah sakit bertanggung jawab terhadap pengelolaan limbah yang dihasilkannya secara tepat dan sesuai prosedur, memenuhi standar pelayanan, keamanan, serta keselamatan dan kesehatan kerja agar tidak menyebabkan kelukaan dan penularan penyakit kepada petugas kebersihan, dokter, perawat, pasien, pengunjung dan pihak rumah sakit.

Berdasarkan Keputusan Menteri Nomor 1087 Mengenai Standar Kesehatan dan Keselamatan Kerja di Rumah Sakit bahwa pekerja di rumah sakit berisiko 1,5 kali lebih besar tertular penyakit seperti HIV setelah luka tusuk. Risiko penularan HIV setelah luka tusuk jarum suntik $4: 1000$. Risiko penularan HBV 27-37 : 100. Sedangkan risiko penularan HCV 3-10 : 100.

Setiap proses pada pengelolaan limbah medis rumah sakit memiliki potensi menyebabkan timbulnya penyakit akibat kerja dan kecelakaan kerja yang dapat menimbulkan banyak kerugian materi dan non materi maupun mengakibatkan korban jiwa. Rumah Sakit Muhammadiyah Lamongan merupakan rumah sakit yang sudah mengelola limbahnya secara mandiri baik limbah medis maupun non medis. Rumah Sakit Muhammadiyah Lamongan (RSML) telah memiliki dua insenerator dan Instalasi Pengelolaan Air Limbah (IPAL) untuk pengelolaan limbah yang dihasilkan. Selain mengelola limbahnya sendiri, RSML juga mengelola limbah medis dari rumah sakit lain yang belum mampu mengelola limbah medisnya secara mandiri.

Berdasarkan laporan unit pengelolaan limbah medis Rumah Sakit Muhammadiyah Lamongan, limbah medis yang dihasilkan rumah sakit rata-rata sekitar 80-85 kilogram per hari. Limbah medis yang dihasilkan memiliki potensi yang sangat besar menimbulkan penyakit dan apabila petugas pengelola tidak melakukan proses pengelolaan secara tepat dan sesuai dengan prosedur. Untuk menghindari timbulnya penyakit akibat kerja dan kecelakaan kerja maka perlu dilakukan identifikasi bahaya pada proses pengelolaan limbah, khususnya limbah medis agar dapat diketahui upaya pengendalian yang tepat.

Tujuan penelitian ini adalah untuk melakukan identifikasi bahaya, analisis risiko dan evaluasi risiko pada proses pengelolaan limbah medis rumah sakit. Risiko di identifikasi dengan menggunakan metode Task Risk Assessment dan dianalisis berdasarkan analisis semi kuantitatif. Manfaat penelitian ini adalah memberikan masukan kepada manajemen rumah sakit agar dapat menciptakan lingkungan yang aman bagi pekerja.

\section{METODE}

Desain penelitian yang digunakan pada penelitian ini merupakan desain penelitian observasional dengan pendekatan cross sectional dan bersifat deskriptif (Notoatmodjo, 2012). Untuk mengetahui tingkat bahaya dan risiko pada proses pengelolaan limbah medis dengan menggunakan metode Task Risk Assessment (TRA) dan berdasarkan standar Australia dan New Zealand. Setiap proses pada pengelolaan limbah medis rumah sakit memiliki potensi menyebabkan timbulnya penyakit akibat kerja dan kecelakaan kerja yang dapat menimbulkan banyak kerugian materi dan non materi maupun mengakibatkan korban jiwa (AS/NZS 4360 : 2004).

Penelitian dilakukan pada April 2013 sampai Juni 2014, berlokasi di Rumah Sakit Muhammadiyah Lamongan. Responden penelitian terdiri dari petugas kebersihan rumah sakit yang bertugas mengelola limbah medis Rumah Sakit Muhammadiyah Lamongan. Penelitian dilakukan di Rumah Sakit Muhammadiyah Lamongan terhadap 6 responden yang diobservasi dan diwawancarai memiliki tugas berbeda-beda dalam pekerjaanya. Responden yang diobservasi serta diwawancarai yaitu 1 petugas pengangkut limbah medis semua area (kecuali kamar operasi, IGD dan ICU), 1 petugas pengangkut limbah medis dari IGD dan ICU, 1 petugas pengangkut limbah medis dari kamar operasi, 1 petugas pemilah limbah medis, dan 2 petugas incinerator. 
Tabel 1. Tingkat Risiko Semi Kuantitatif

\begin{tabular}{lll}
\hline Tingkat Risiko & Kategori & Tindakan \\
\hline 350 & $\begin{array}{l}\text { Sangat } \\
\text { tinggi }\end{array}$ & $\begin{array}{l}\text { Aktivitas dihentikan } \\
\text { sampai risiko bisa } \\
\text { dikurangi hingga } \\
\text { batasan yang } \\
\text { diperbolehkan }\end{array}$ \\
\hline $180-350$ & Prioritas 1 & $\begin{array}{l}\text { Perlu pengendalian } \\
\text { sesegera mungkin }\end{array}$ \\
\hline $70-180$ & Besar & $\begin{array}{l}\text { Mengharuskan adanya } \\
\text { perbaikan secara teknis }\end{array}$ \\
\hline $20-70$ & Prioritas 3 & $\begin{array}{l}\text { Perlu diawasi dan } \\
\text { diperhatikan secara } \\
\text { berkesinambungan }\end{array}$ \\
\hline & Diterima & $\begin{array}{l}\text { Intensitas yang } \\
\text { menimbulkan risiko } \\
\text { dikurangi seminimal } \\
\text { mungkin }\end{array}$ \\
\hline
\end{tabular}

Sumber: Risk Management Guidelines Companion AS/NZS 4360:2004

Variabel dalam penelitian ini yaitu potensi bahaya, penilaian risiko serta upaya pengendalian terhadap risiko pada proses pengelolaan limbah medis. Identifikasi potensi bahaya kesehatan dan keselamatan kerja serta upaya pengendalian risiko pada proses pengelolaan limbah medis rumah sakit dilakukan dengan menggunakan metode Task Risk Assessment (TRA). Semua potensi bahaya yang diperoleh kemudian diberi penilaian konsekuensi (consequences), kemungkinan (likelihood), dan paparan (exposure) kemudian dilakukan perhitungan untuk melihat tingkat risiko bahaya. Tingkat risiko diperoleh dari melakukan perkalian antara konsekuensi (consequences), kemungkinan (likelihood), dan paparan (exposure). Analisis dan evaluasi risiko dilakukan untuk melakukan penilaian terhadap risiko dengan menggunakan standar Australia dan New Zealand (AS/NZS 4360 : 2004).

\section{HASIL \\ Identifikasi Bahaya}

Identifikasi bahaya merupakan proses yang dilaksanakan untuk mencari tahu dan mencoba memahami kemungkinan ancaman bahaya yang akan terjadi di tempat kerja. Identifikasi bahaya adalah langkah awal dari manajemen risiko. Menurut hasil observasi yang telah dilakukan Rumah Sakit Muhammadiyah Lamongan telah memiliki Instalasi Pengelolaan Air Limbah (IPAL) dan 2 insenerator untuk pemusnahan limbah medis yang telah memiliki izin operasional. Setiap proses kerja memiliki berbagai macam bahaya yang berbeda sehingga perlu dilakukan identifikasi. Hasil identifikasi bahaya pada proses pengelolaan limbah medis Rumah Sakit Muhammadiyah Lamongan dengan menggunakan metode TRA. Tahap pengelolaan limbah medis dibagi menjadi empat tahap, yaitu pemilahan limbah medis yang sudah terkumpul, proses penggilingan (grinding) dan proses pemusnahan limbah medis dengan menggunakan insenerator. Potensi bahaya

Tabel 2. Hasil Identifikasi Bahaya

\begin{tabular}{lll}
\hline Jenis Bahaya & \multicolumn{1}{c}{ Bahaya } & \multicolumn{1}{c}{ Dampak } \\
\hline Bahaya Fisik & Kebisingan & Gangguan komunikasi \\
& Pencahayaan & Kelelahan mata \\
& Kelembaban & Dehidrasi \\
& Suhu tinggi & Dehidrasi \\
& Terpeleset & Cidera \\
& Tertusuk benda tajam & Luka tusuk \\
& Serbuk grinding masuk mata & Iritasi mata \\
& Tergores pintu insenerator & Luka gores \\
& Kebakaran & Cidera dan kematian \\
& Peledakan & Cidera dan kematian \\
\hline Bahaya Kimia & Debu & Gangguan pernafasan \\
& Kontak deterjen & Iritasi kulit \\
& Kontak disinfektan & Iritasi kulit \\
& Bau menyengat & Mual dan atau muntah \\
\hline
\end{tabular}


yang ditimbulkan dari proses pengelolaan limbah medis yang dilakukan petugas pengelola limbah medis Rumah Sakit Muhammadiyah Lamongan terdapat pada Tabel 2 .

Berdasarkan observasi dan wawancara dengan petugas pengangkut limbah medis Rumah Sakit Muhammadiyah Lamongan, tahap pengangkutan limbah medis terdiri dari proses pengambilan seluruh limbah medis dari sumbernya, penggantian kontainer yang telah penuh limbah medis dengan kontainer kosong dan proses pengangkutan limbah medis ke tempat pengumpulan sementara khusus limbah medis. Tahapan proses pemilahan limbah medis yaitu proses pemilahan limbah medis sesuai jenisnya, pemasukan limbah medis ke dalam plastik khusus limbah medis, pemasukan limbah medis ke ruangan tempat penampungan sementara khusus limbah medis dan proses pembersihan tempat pemilahan limbah medis.

Tahapan proses kerja penggilingan (grinding) adalah mengambil limbah botol kaca dari tempat penampungan sementara, memasukkan limbah botol kaca ke dalam alat penggilingan (grinding) khusus dan tahap pengambilan hasil grinding. Tahap proses pemusnahan limbah medis adalah pengambilan limbah medis dari tempat penampungan sementara khusus limbah medis, pengisian bahan bakar insenerator, pemasukan limbah medis ke dalam insenerator, penyalaan insenerator, pemantauan suhu insenerator, dan pengambilan residu pembakaran limbah medis dari insenerator.
Potensi bahaya yang terdapat pada proses pengelolaan limbah medis rumah sakit antara lain bahaya fisik, kimia, biologi dan ergonomi. Potensi bahaya yang ada bisa memicu terjadinya penyakit akibat kerja dan cidera pada petugas pengelola limbah. Hasil identifikasi bahaya pada proses pengelolaan limbah medis rumah sakit dapat disimpulkan bahwa bahaya yang terdapat pada proses pengelolaan limbah medis Rumah Sakit Muhammadiyah Lamongan yaitu bahaya penularan penyakit, potensi bahaya cidera karena benda tajam, kondisi lingkungan fisik yang tidak memenuhi standar, bahaya kebakaran, peledakan, posisi tubuh yang tidak ergonomi saat bekerja, dan bahaya kimia.

\section{Penilaian Risiko}

Penilaian risiko merupakan tahap untuk melakukan analisis risiko dan evaluasi risiko. Pada tahap analisis risiko dapat diperoleh nilai konsekuensi, paparan dan kemungkinan. Pada tahap evaluasi risiko dapat diperoleh nilai tingkat risiko. Pajanan yang ditimbulkan oleh limbah medis yang berbahaya dapat mengakibatkan penyakit dan ataupun cidera.

Berdasarkan hasil analisis risiko pada tahap pengangkutan limbah medis, luka tusuk dan risiko terinfeksi penyakit akibat kontak dengan limbah medis memiliki tingkat risiko prioritas 1 yang berarti perlu pengendalian sesegera mungkin.

Tabel 3. Hasil Penilaian pada Tahap Pengangkutan Limbah Medis

\begin{tabular}{|c|c|c|c|c|c|}
\hline \multirow{2}{*}{ Potensi Bahaya } & \multicolumn{3}{|c|}{ Basic Risk } & \multirow{2}{*}{$\begin{array}{c}\text { Nilai } \\
\text { Risiko }\end{array}$} & \multirow{2}{*}{$\begin{array}{c}\text { Tingkat } \\
\text { Risiko }\end{array}$} \\
\hline & Consequences & Exposure & Likelihood & & \\
\hline Kontak dengan limbah infeksius & 15 (Serious) & 10 (Continuously) & $\begin{array}{l}3 \text { (Unsure but } \\
\text { possible) }\end{array}$ & 300 & Prioritas 1 \\
\hline $\begin{array}{l}\text { Tertusuk jarum atau limbah } \\
\text { medis tajam lainnya }\end{array}$ & 15 (Serious) & 10 (Continuously) & $\begin{array}{c}3 \text { (Unsure but } \\
\text { possible) }\end{array}$ & 300 & Prioritas 1 \\
\hline $\begin{array}{l}\text { Terpeleset karena lantai ruangan } \\
\text { licin }\end{array}$ & 1 (Noticeable) & 10 (Continuously) & $\begin{array}{l}3 \text { (Unsure but } \\
\text { possible) }\end{array}$ & 30 & Prioritas 3 \\
\hline Menghirup debu ruangan & 1 (Noticeable) & 10 (Continuously) & $\begin{array}{l}2 \text { (Remotely } \\
\text { possible) }\end{array}$ & 20 & Prioritas 3 \\
\hline Terpapar bising & 1 (Noticeable) & 10 (Continuously) & 1 (Conceivable) & 10 & Diterima \\
\hline $\begin{array}{l}\text { Pencahayaan yang tidak } \\
\text { memenuhi standar }\end{array}$ & 1 (Noticeable) & 10 (Continuously) & 1 (Conceivable) & 10 & Diterima \\
\hline $\begin{array}{l}\text { Kelembapan/suhu ruangan yang } \\
\text { tidak memenuhi standar }\end{array}$ & 1 (Noticeable) & 10 (Continuously) & 10 (Almost certain) & 100 & Besar \\
\hline $\begin{array}{l}\text { Pekerjaan berdiri dan berjalan } \\
\text { secara terus menerus }\end{array}$ & 1 (Noticable) & 10 (Continously) & 6 (Likely) & 60 & Prioritas 3 \\
\hline
\end{tabular}


Tabel 3. Hasil Penilaian Risiko pada Tahap Pemilahan Limbah Medis

\begin{tabular}{|c|c|c|c|c|c|}
\hline \multirow{2}{*}{ Potensi Bahaya } & \multicolumn{3}{|c|}{ Basic Risk } & \multirow{2}{*}{$\begin{array}{l}\text { Nilai } \\
\text { Risiko }\end{array}$} & \multirow{2}{*}{$\begin{array}{l}\text { Tingkat } \\
\text { Risiko }\end{array}$} \\
\hline & Consequences & Exposure & Likelihood & & \\
\hline $\begin{array}{l}\text { Tertusuk jarum dan } \\
\text { limbah medis lain yang } \\
\text { tajam }\end{array}$ & 15 (Serious) & 6 (frequently) & 6 (Likely) & 540 & Sangat tinggi \\
\hline $\begin{array}{l}\text { Posisi duduk yang tidak } \\
\text { ergonomis }\end{array}$ & 1 (Noticeable) & 6 (Frequently) & 10 (Almost certain) & 60 & Prioritas 3 \\
\hline $\begin{array}{l}\text { Kontak dengan virus dan } \\
\text { bakteri }\end{array}$ & 5 (Important) & 3 (Occasionally) & 2 (Likely) & 30 & Prioritas 3 \\
\hline $\begin{array}{l}\text { Kontak dengan } \\
\text { disinfektan atau detergen }\end{array}$ & 1 (Noticeable) & 3 (Occasionally) & 2 (Remotely possible) & 6 & Diterima \\
\hline Terpeleset saat mengepel & 1 (Noticeable) & 6 (Frequently) & 2 (Remotely possible) & 12 & Diterima \\
\hline $\begin{array}{l}\text { Kontak dengan cairan } \\
\text { pembersih lantai }\end{array}$ & 1 (Noticeable) & 6 (Frequently) & 2 (Remotely possible) & 12 & Diterima \\
\hline
\end{tabular}

Untuk risiko cidera, kelelahan otot, dan gangguan saluran pernapasan memiliki tingkat risiko prioritas 3 yaitu perlu pengawasan dan perhatian secara berkesinambungan terhadap pelaksanaan. Untuk kelelahan mata dan gangguan komunikasi memiliki tingkat risiko diterima yaitu diharapkan bisa mengurangi intensitas yang menimbulkan risiko. Sedangkan untuk risiko dehidrasi dan kenaikan suhu tubuh tingkat risiko besar sehingga butuh perbaikan secara teknis.

Berdasarkan hasil analisis risiko pada tahap pemilahan limbah medis risiko luka tusuk dan terinfeksi penyakit karena tertusuk jarum yang infeksius memiliki tingkat risiko sangat tinggi sehingga harus mengurangi paparan. Untuk risiko nyeri otot karena posisi duduk yang kurang ergonomis memiliki tingkat risiko prioritas 3 sehingga butuh pengawasan terhadap proses kerja.

Untuk risiko terinfeksi penyakit akibat kontak dengan virus atau bakteri memiliki tingkat risiko prioritas 3 yaitu butuh pengawasan terhadap proses kerja. Risiko iritasi kulit dan cidera saat mengepel lantai memiliki tingkat risiko diterima sehingga perlu mengurangi intensitas yang menimbulkan risiko.

Berdasarkan hasil analisis risiko pada tahap grinding limbah medis botol kaca risiko luka tusuk memiliki tingkat risiko diterima sehingga hanya membutuhkan pengurangan intensitas paparan.

Untuk gangguan saluran pernapasan dan cidera mata memiliki tingkat risiko prioritas 3 sehingga perlu pengawasan terhadap proses kerja. Untuk gangguan pendengaran memiliki tingkat risiko

Tabel 4. Hasil Penilaian Risiko pada Tahap Penggilingan (Grinding)

\begin{tabular}{|c|c|c|c|c|c|}
\hline \multirow{2}{*}{ Potensi Bahaya } & \multicolumn{3}{|c|}{ Basic Risk } & \multirow{2}{*}{$\begin{array}{c}\text { Nilai } \\
\text { Risiko }\end{array}$} & \multirow{2}{*}{$\begin{array}{c}\text { Tingkat } \\
\text { Risiko }\end{array}$} \\
\hline & Consequences & Exposure & Likelihood & & \\
\hline Tertusuk botol kaca yang pecah & 1 (Noticeable) & 2 (Infrequently) & 2 (Remotely possible) & 4 & Diterima \\
\hline $\begin{array}{l}\text { Menghirup serbuk hasil } \\
\text { penggilingan (grinding) }\end{array}$ & 15 (Serious) & 2 (Infrequently) & 1 (Conceivable) & 30 & Prioritas 3 \\
\hline $\begin{array}{l}\text { Bising yang dihasilkan mesin } \\
\text { saat proses penggilingan } \\
\text { (grinding) }\end{array}$ & 15 (Serious) & 2 (Infrequently) & 3 (Unsure but possible) & 90 & Besar \\
\hline $\begin{array}{l}\text { Bau yang menyengat yang } \\
\text { dihasilkan saat proses } \\
\text { penggilingan (grinding) }\end{array}$ & 1 (Noticeable) & 2 (Infrequently) & 6 (Likely) & 12 & Diterima \\
\hline $\begin{array}{l}\text { Serbuk hasil penggilingan } \\
\text { (grinding) masuk mata }\end{array}$ & 15 (Serious) & 2 (Infrequently) & 1 (Conceivable) & 30 & Prioritas 3 \\
\hline
\end{tabular}


Tabel 5. Hasil Penilaian Risiko pada Tahap Pemusnahan Limbah Medis

\begin{tabular}{|c|c|c|c|c|c|}
\hline \multirow{2}{*}{ Potensi Bahaya } & \multicolumn{3}{|c|}{ Basic Risk } & \multirow{2}{*}{$\begin{array}{l}\text { Nilai } \\
\text { Risiko }\end{array}$} & \multirow{2}{*}{$\begin{array}{l}\text { Tingkat } \\
\text { Risiko }\end{array}$} \\
\hline & Consequences & Exposure & Likelihood & & \\
\hline $\begin{array}{l}\text { Tertusuk limbah medis yang } \\
\text { tajam }\end{array}$ & 15 (Serious) & 6 (Frequently) & 6 (Likely) & 540 & Sangat tinggi \\
\hline Kontak dengan limbah infeksius & 15 (Serious) & 6 (Frequently) & 6 (Likely) & 540 & Sangat tinggi \\
\hline $\begin{array}{l}\text { Terjepit atau terkena goresan } \\
\text { pintu insenerator }\end{array}$ & 1 (Noticeable) & 6 (Frequently) & 10 (Almost certain) & 60 & Prioritas 3 \\
\hline $\begin{array}{l}\text { Residu pembakaran limbah } \\
\text { medis terhirup }\end{array}$ & 15 (Serious) & 6 (Frequently) & 6 (Likely) & 540 & Sangat tinggi \\
\hline Peledakan insenerator & 50 (Disaster) & 6 (Frequently) & 1 (Conceivable) & 300 & Prioritas 1 \\
\hline Kebakaran & 50 (Disaster) & 6 (Frequently) & 1 (Conceivable) & 300 & Sangat tinggi \\
\hline $\begin{array}{l}\text { Menghirup udara yang bersifat } \\
\text { dioxin }\end{array}$ & 15 (Serious) & 6 (Frequently) & 10 (Almost certain) & 900 & Sangat tinggi \\
\hline $\begin{array}{l}\text { Pelepasan panas yang tinggi } \\
\text { karena pembakaran dengan suhu } \\
\geq 1000^{\circ} \mathrm{C}\end{array}$ & 1 (Noticeable) & 6 (Frequently) & 6 (Likely) & 36 & Prioritas 3 \\
\hline $\begin{array}{l}\text { Menghirup residu hasil } \\
\text { pembakaran }\end{array}$ & 5 (Important) & 6 (Frequently) & 3 (Unsure but possible) & 90 & Besar \\
\hline
\end{tabular}

besar sehingga butuh perbaikan teknis. Gangguan kesehatan berupa nausea, vomiting dan sakit kepala yang diakibatkan oleh bau menyengat saat proses butuh alat pelindung diri yang sesuai.

Berdasarkan hasil analisis risiko pada tahap pemusnahan limbah medis risiko luka tusuk, tertular penyakit dan gangguan saluran pernapasan memiliki tingkat risiko sangat tinggi yang artinya butuh pengurangan paparan. Untuk risiko luka gores, heat stress, iritasi mata, dan dehidrasi memiliki tingkat prioritas 3 yang berarti perlu adanya pengawasan terhadap proses kerja. Untuk risiko cidera dan kematian petugas akibat peledakan dan kebakaran memiliki tingkat risiko prioritas 1 sehingga perlu adanya pengendalian secara teknis. Risiko gangguan saluran pernapasan akut memiliki tingkat risiko besar yaitu perlu adanya perbaikan secara teknis.

\section{Upaya Pengendalian Risiko}

Pengendalian teknis termasuk mengubah struktur objek kerja untuk mencegah seseorang terpapar kepada potensi bahaya. Pengendalian administrasi dilakukan dengan menyediakan suatu system kerja yang mengurangi kemungkinan seseorang terpapar potensi bahaya. Alat pelindung diri (APD) secara umum merupakan pilihan terakhir dari suatu sistem pengendalian risiko di tempat kerja. Penggunaan alat pelindung diri tidak menghilangkan risiko bahaya yang ada, tetapi membatasi paparan. Bila penggunaan alat pelindung diri gagal, maka bahaya mengenai tubuh pekerja. Pengendalian teknis yang dilakukan oleh rumah sakit terhadap risiko yang ada pada proses pengelolaan limbah medis rumah sakit yaitu penyediaan troli khusus untuk pengangkutan limbah medis. Selain itu dilakukan penutupan lubang keluar hasil grinding dengan timbah dan penggunaan alat bantu berupa tongkat besi untuk memasukkan limbah medis ke insenerator. Upaya pengendalian risiko yang dilakukan oleh Rumah Sakit Muhammadyah Lamongan terhadap proses pengelolaan limbah medis yang dihasilkan adalah pengendalian secara teknik berupa penyediaan troli khusus, menutup lubang keluar hasil grinding dengan timbah, tongkat khusus untuk memasukkan limbah medis ke insenerator, mengatur jarak aman, serta sistem pengaman otomatis seperti water sprayer dan pendinginan otomatis. Rumah sakit juga melakukan pengendalian administratif dengan pembagian shift, adanya standar operating procedure, adanya warning sign, penyediaan sabun cuci tangan khusus, serta adanya tata cara penggunaan alat pelindung diri yang ditempel di ruangan insenerator. Alat pelindung diri (APD) yang disediakan rumah sakit untuk digunakan petugas pengelola limbah medis berupa masker disposable, heavy duty gloves, disposable gloves, sepatu boots, serta safety shoes. 


\section{PEMBAHASAN}

\section{Identifikasi Bahaya}

Hasil identifikasi bahaya dilakukan dengan menggunakan data primer berdasarkan observasi dan wawancara kepada petugas pengelola limbah medis yang bertugas sebagai pengangkut limbah medis, pemilah limbah medis, petugas penggilingan (grinding), dan petugas pemusnah limbah medis dengan insenerator. Menurut Harrianto (2008), potensi bahaya yang dapat menyebabkan gangguan kesehatan ataupun kecelakaan kerja adalah bahaya fisik, kimia, biologis, ergonomis, dan psikologis. Bahaya biologi yang terdapat pada proses pengelolaan limbah medis adalah penularan penyakit melalui kontaminasi virus, fungi, dan atau bakteri.

Bahaya fisik yang ada pada proses pengelolaan limbah medis yaitu terpeleset, tertusuk jarum suntik atau benda tajam lainnya, kebisingan, pencahayaan yang tidak memenuhi standar di beberapa ruangan, suhu dan kelembapan yang tidak memenuhi standar di beberapa ruangan, tergores pintu insenerator, peledakan, kebakaran, serta pelepasan panas yang tinggi. Bahaya kimia yang terdapat pada proses pengelolaan limbah medis yaitu kontak dengan disinfektan, detergen, cairan pembersih lantai, debu, serbuk hasil grinding, bau menyengat saat grinding, residu pembakaran, serta udara yang bersifat dioxin. Bahaya ergonomi yang ada yaitu posisi kerja berdiri dan berjalan terus-menerus, serta posisi duduk yang tidak ergonomi.

Potensi bahaya biologi yang ada pada proses pengelolaan limbah medis yaitu terinfeksi virus dan penyakit menular seperti Human Immunodeficiency Virus (HIV), Hepatitis B Virus (HBV), Hepatitis $C$ Virus (HCV), Tuberculosis, Cytomegalovirus, dan Rubella. Hasil pengukuran kebisingan, pencahayaan, suhu, dan kelembapan pada beberapa ruangan di Rumah Sakit Muhammadiyah Lamongan menunjukkan ketidaksesuaian dengan standar berdasarkan Keputusan Menteri Kesehatan No. 1204 Tentang Persyaratan Kesehatan Lingkungan Rumah Sakit.

\section{Penilaian Risiko}

Hasil analisis risiko pada proses pengelolaan limbah medis rumah sakit yaitu konsekuensi (consequences) dari kontak dengan limbah dapat memberikan dampak cidera, menimbulkan penyakit, dan atau penularan penyakit. Pekerjaan yang dilakukan setiap hari oleh petugas pengelola limbah yaitu pengangkutan, pemilahan dan pembakaran limbah medis. Penggilingan (grinding) dilakukan sebulan sekali. Kejadian gangguan kesehatan atau kecelakaan kemungkinan terjadi yaitu kelelahan otot, luka tusuk, terinfeksi penyakit, nausea, vomiting, gangguan saluran pernapasan, heat stress, iritasi mata, dan dehidrasi. Berdasarkan evaluasi risiko pada proses pengelolaan limbah medis rumah sakit diketahui bahwa terdapat enam risiko sangat tinggi, tiga risiko prioritas 1, tiga risiko besar, sembilan risiko prioritas 3 , dan tujuh risiko diterima. Berdasarkan standar Australia dan New Zealand (AS/NZS 4360:2004), sebagai upaya mengurangi risiko yang sangat tinggi maka dibutuhkan upaya untuk mengurangi paparan terhadap pekerja. Untuk risiko dengan prioritas 1 perlu adanya pengendalian sesegera mungkin baik secara teknik, administratif maupun alat pelindung diri. Untuk risiko besar dan prioritas 3 perlu pengawasan secara berkesinambungan terhadap penggunaan alat pelindung diri (APD). Risiko yang berpotensi terjadi pada tahap pengangkutan limbah medis yaitu kontak dengan limbah infeksius yang dapat menjadi sarana penularan penyakit, hal itu bisa terjadi jika petugas tidak menggunakan alat pelindung diri yang sesuai dan limbah medis tidak ditempatkan di wadah yang sesuai. Ketidakpatuhan petugas dalam penggunaan alat pelindung diri yang sesuai merupakan unsafe actions. Keadaan limbah medis tidak diletakkan pada wadah yang seharusnya merupakan unsafe condition. Risiko yang berpotensi terjadi pada tahap pengangkutan limbah medis yaitu petugas dapat tertusuk jarum suntik saat mengambil limbah medis dari wadah di setiap ruangan. Hal itu bisa terjadi jika tidak petugas tidak menggunakan gloves dan baju coverall saat bekerja serta petugas medis tidak menutup jarum secara sempurna. Risiko yang berpotensi terjadi pada tahap pengangkutan limbah medis yaitu terpeleset karena lantai ruangan licin, hal itu bisa terjadi jika petugas tidak menggunakan safety shoes dan tidak ada warning sign jika lantai licin setelah dipel.

Bising yang terjadi dapat mengakibatkan dampak atau gangguan ringan seperti gangguan komunikasi. Berdasarkan hasil observasi dan wawancara kejadian ini jarang terjadi namun mempunyai kemungkinan terjadi. Risiko yang berpotensi terjadi pada tahap pengangkutan limbah medis yaitu terpapar bising karena di beberapa ruangan penghasil limbah medis tingkat kebisingannya tidak memenuhi standar menurut 
berdasarkan Keputusan Menteri Kesehatan No. 1204 tentang persyaratan kesehatan lingkungan rumah sakit.

Pada saat petugas melakukan penggilingan (grinding) limbah medis botol kaca, petugas pengelola limbah berpotensi menghirup serbuk hasil proses penggilingan (grinding). Kegiatan penggilingan (grinding) hanya dilakukan satu bulan sekali. Berdasarkan hasil observasi dan wawancara kejadian ini belum pernah terjadi selama bertahun-tahun paparan karena petugas menggunakan masker pelindung namun mungkin saja terjadi.

Pada saat petugas melakukan penggilingan (grinding) limbah medis botol kaca, petugas pengelola limbah berpotensi menghirup serbuk hasil proses penggilingan (grinding). Kegiatan penggilingan (grinding) hanya dilakukan satu bulan sekali. Berdasarkan hasil observasi dan wawancara kejadian ini belum pernah terjadi selama bertahun-tahun paparan karena petugas menggunakan masker pelindung namun mungkin saja terjadi. Pada saat petugas melakukan grinding limbah medis yang mengganggu. Risiko yang berpotensi terjadi pada tahap penggilingan (grinding) limbah medis yaitu potensi menghirup bau menyengat yang dihasilkan dari proses penggilingan (grinding). Hal itu bisa terjadi jika tidak petugas tidak menggunakan masker khusus saat bekerja. Hasil observasi menunjukkan bahwa petugas hanya menggunakan masker disposable. Pada saat petugas melakukan penggilingan (grinding) limbah medis botol kaca, mesin menghasilkan suara yang mengganggu. Risiko yang berpotensi terjadi pada tahap penggilingan (grinding) limbah medis botol kaca yaitu terpapar bising mesin penggilingan (grinding). Kebisingan merupakan unsafe conditions. Pada saat petugas melakukan pemusnahan limbah medis, berpotensi terjadinya kebakaran insenerator karena saat pembakaran dilakukan water sprayer tidak dinyalakan. Berdasarkan observasi dan wawancara kejadian ini pernah terjadi namun tidak biasa terjadi. Risiko yang berpotensi terjadi pada tahap pemusnahan limbah medis yaitu terjadinya kebakaran pada insenerator.

Pada saat proses pemusnahan limbah medis, petugas pengelola limbah berpotensi menghirup udara yang bersifat dioxin. Risiko yang berpotensi terjadi pada tahap pemusnahan limbah medis yaitu petugas dapat menghirup udara yang bersifat dioxin. Hal itu bisa terjadi jika tidak petugas tidak menggunakan masker khusus saat bekerja serta pembakaran tidak dengan suhu yang sesuai untuk pembakaran limbah medis. Pada saat proses pemusnahan, suhu yang digunakan tinggi sehingga ada pelepasan panas tinggi di sekitar insenerator. Risiko yang berpotensi terjadi pada tahap pemusnahan limbah medis yaitu petugas terpapar suhu tinggi. Suhu yang tinggi merupakan unsafe condition. Pada saat petugas mengambil residu sisa pemusnahan, petugas pengelola limbah berpotensi menghirup residu yang berbentuk abu. Risiko yang berpotensi terjadi pada tahap pemusnahan limbah medis yaitu petugas dapat menghirup residu pembakaran saat mengambil sisa pembakaran dari dalam insenerator. Hal itu bisa terjadi jika petugas tidak menggunakan masker saat bekerja. Ketidakpatuhan petugas dalam penggunaan alat pelindung diri yang sesuai merupakan unsafe actions.

Pada saat petugas melakukan pemusnahan limbah medis, berpotensi terjadinya peledakan insenerator karena pembakaran dilakukan dengan suhu tinggi. Risiko yang berpotensi terjadi pada tahap pemusnahan limbah medis yaitu terjadinya peledakan insenerator. Hal itu bisa terjadi jika petugas tidak bekerja sesuai dengan standar prosedur yang ada. Selain itu, fungsi pendingin dan fungsi off mesin secara otomatis tidak berfungsi semestinya juga dapat memicu terjadinya peledakan.

Pada saat petugas memasukkan limbah medis sebelum proses pemusnahan, petugas pengelola limbah berpotensi menghirup sisa pembakaran yang ada dalam insenerator. Berdasarkan hasil observasi dan wawancara pemusnahan limbah medis dilakukan dua kali dalam sehari yaitu pukul 08.00 WIB dan pukul 13.00 WIB. Risiko yang berpotensi terjadi pada tahap pemusnahan limbah medis yaitu petugas dapat menghirup residu pembakaran.

Pada saat petugas memasukkan limbah medis sebelum proses pemusnahan, petugas pengelola limbah berpotensi terjepit atau terkena goresan pintu insenerator. Risiko yang berpotensi terjadi pada tahap pemusnahan limbah medis yaitu petugas dapat tergores pintu insenerator saat membuka dan menutup pintu insenerator. Hal itu bisa terjadi jika tidak petugas tidak menggunakan gloves saat bekerja serta petugas medis tidak menutup jarum secara sempurna.

Pada proses pemusnahan limbah medis petugas pengelola limbah berpotensi kontak dengan limbah infeksius. Risiko yang berpotensi terjadi pada tahap pemusnahan limbah medis yaitu kontak dengan limbah infeksius yang dapat menjadi 
sarana penularan penyakit. Hal itu bisa terjadi jika petugas tidak menggunakan alat pelindung diri yang sesuai serta tidak menggunakan alat bantu saat memasukkan limbah medis ke dalam insenerator. Pada proses pemusnahan, petugas pengelola limbah berpotensi tertusuk jarum suntik dan limbah medis tajam lainnya saat memasukkan limbah medis ke dalam insenerator. Pemusnahan limbah medis dilakukan dua kali dalam sehari. Risiko yang berpotensi terjadi pada tahap pemusnahan limbah medis yaitu petugas dapat tertusuk jarum suntik saat memasukkan limbah medis ke dalam insenerator. Hal itu bisa terjadi jika petugas tidak menggunakan gloves dan baju coverall saat bekerja serta petugas medis tidak menutup jarum secara sempurna.

\section{Upaya Pengendalian Risiko}

Pengendalian risiko merupakan langkah penting dan menentukan dalam keseluruhan manajemen risiko. Dari hasil identifikasi bahaya dan penilaian risiko maka selanjutnya dilakukan pengendalian bahaya. OHSAS 18001 dalam Ramli (2010) memberikan pedoman pengendalian risiko yang lebih spesifik untuk bahaya kesehatan dan keselamatan kerja dengan pendekatan eliminasi, substitusi, pengendalian teknis, pengendalian administratif dan penggunaan alat pelindung diri (APD). Jika ditinjau dengan yang telah dikemukakan Ramli (2010), upaya pengendalian pada proses pengelolaan limbah medis di Rumah Sakit Muhammadiyah Lamongan yaitu dengan rekayasa teknik berupa penyediaan troli khusus, menutup lubang keluar hasil grinding dengan timbah, tongkat khusus untuk memasukkan limbah medis ke insenerator, mengatur jarak aman, serta sistem pengaman otomatis seperti water sprayer dan pendinginan otomatis. Pengendalian secara administratif dengan pembagian shift, pengadaan standar operating procedure, adanya warning sign, penyediaan sabun cuci tangan khusus, serta adanya tata cara penggunaan alat pelindung diri yang ditempel di ruangan insenerator. Alat pelindung diri (APD) yang disediakan rumah sakit yaitu berupa masker disposable, heavy duty gloves, disposable gloves, sepatu boots, serta safety shoes. Petugas yang menangani limbah harus menggunakan alat pelindung diri (APD) yang terdiri atas topi/helm masker khusus atau respirator (terutama untuk petugas insenerator dan grinding), pelindung mata (terutama untuk petugas insenerator dan grinding), pakaian panjang (coverall), safety shoes atau sepatu boots, sarung tangan khusus (disposable gloves atau heavy duty gloves).
Pengendalian dengan alat pelindung diri yang dilakukan oleh rumah sakit terhadap risiko yang ada pada proses pengelolaan limbah medis dan digunakan oleh petugas adalah safety shoes, masker disposable, sarung tangan disposable untuk petugas insenerator dan petugas grinding, serta heavy duty gloves untuk petugas pengangkut dan pemilahan limbah medis. Petugas pengelola limbah medis tidak menggunakan baju coverall dan penutup kepala saat bekerja. Selain itu, petugas grinding dan petugas insenerator tidak menggunakan pelindung mata, earplug, dan masker khusus saat bekerja. Menurut Tarwaka (2008), masker yang sesuai untuk proses yang berhubungan dengan kontaminasi gas dan uap dengan toksisitas rendah adalah chemical respirator. Alat pelindung diri tersebut sesuai dengan proses grinding yang menghasilkan uap dan gas dari bahan kimia sehingga seharusnya petugas menggunakan chemical respirator.

\section{SIMPULAN}

Berdasarkan hasil penelitian mengenai identifikasi bahaya, penilaian risiko dan upaya pengendalian pada proses pengelolaan limbah medis di Rumah Sakit Muhammadiyah Lamongan, dapat disimpulkan hasil identifikasi bahaya pada proses pengelolaan limbah medis rumah sakit dapat disimpulkan bahwa bahaya yang terdapat pada proses pengelolaan limbah medis Rumah Sakit Muhammadiyah Lamongan yaitu bahaya penularan penyakit, potensi bahaya cidera karena benda tajam, kondisi lingkungan fisik yang tidak memenuhi standar, bahaya kebakaran, peledakan, posisi tubuh yang tidak ergonomi saat bekerja, dan bahaya kimia.

Hasil analisis risiko pada proses pengelolaan limbah medis rumah sakit yaitu konsekuensi (consequences) dari kontak dengan limbah dapat memberikan dampak cidera, menimbulkan penyakit, dan atau penularan penyakit. Pekerjaan yang dilakukan setiap hari oleh petugas pengelola limbah yaitu pengangkutan, pemilahan dan pembakaran limbah medis. Penggilingan (grinding) dilakukan sebulan sekali. Kejadian gangguan kesehatan atau kecelakaan kemungkinan terjadi yaitu kelelahan otot, luka tusuk, terinfeksi penyakit, nausea, vomiting, gangguan saluran pernapasan, heat stress, iritasi mata, dan dehidrasi. Hasil evaluasi risiko pada proses pengelolaan limbah medis rumah sakit diketahui bahwa terdapat 6 risiko sangat tinggi, 3 risiko prioritas 1, 3 risiko besar, 9 risiko prioritas 
3, dan 7 risiko diterima. Upaya pengendalian yang dilakukan oleh rumah sakit terhadap risiko yaitu meliputi rekayasa teknik, pengendalian administratif serta pengadaan alat pelindung diri (APD).

\section{DAFTAR PUSTAKA}

Australia/New Zealand Standard, AS/NZS 4360, 2004. Risk Management Standards. Australia.

Depkes RI. 2006. Limbah Medis Rumah Sakit. Jakarta: [Accesed 11 Nopember 2013] http:// www.depkes.go.id/index.php?vw=2\&id=879.

Harrianto, R. 2008. Buku Ajaran Kesehatan Kerja. Jakarta: EGC.

Keputusan Menteri Kesehatan Nomor 1087 Tahun 2010. Mengenai Standar Kesehatan dan Keselamatan Kerja di Rumah Sakit. Jakarta: Kementerian Kesehatan.
Keputusan Menteri Kesehatan No. 1204 tahun 2004 tentang Persyaratan Kesehatan Lingkungan Rumah Sakit. Jakarta: Kementerian Kesehatan.

Notoatmodjo, Soekidjo. 2012. Metodologi Penelitian Kesehatan. Jakarta: Rineka Cipta.

Ramli, S. 2010. Pedoman Praktis Manajemen Risiko dalam Prespektif K3 OHS Risk Management. Jakarta: Dian Rakyat.

Tarwaka. 2008. Manajemen dan Implementasi Kesehatan dan Keselamatan Kerja di Tempat Kerja. Surakarta: Harapan Press.

Undang-Undang Nomor 44 Tahun 2009 tentang Rumah Sakit. Jakarta: Kementerian Kesehatan. 